\title{
Clinical impact of CD200 expression in patients with acute myeloid leukemia and correlation with other molecular prognostic factors
}

\author{
Daniela Damiani ${ }^{1}$, Mario Tiribelli' ${ }^{1}$, Donatella Raspadori ${ }^{2}$, Santina Sirianni ${ }^{2}$, \\ Alessia Meneghel ${ }^{1}$, Margherita Cavallinn ${ }^{1}$, Angela Michelutti ${ }^{1}$, Eleonora Toffoletti ${ }^{1}$, \\ Antonella Geromin¹, Erica Simeone ${ }^{1}$, Monica Bocchia ${ }^{2}$, Renato Fanin ${ }^{1}$ \\ ${ }^{1}$ Division of Hematology and Bone Marrow Transplantation, Azienda Ospedaliero-Universitaria di Udine, Udine, Italy \\ ${ }^{2}$ Division of Hematology, University of Siena, Siena, Italy \\ Correspondence to: \\ Daniela Damiani, e-mail: daniela.damiani@uniud.it \\ Keywords: CD200, acute myeloid leukemia, prognosis, survival \\ Received: May 18, $2015 \quad$ Accepted: August 07, 2015 \\ Published: August 18, 2015
}

\section{ABSTRACT}

CD200, a protein belonging to the immunoglobulin superfamily, has been associated with a poor prognosis in lymphoproliferative disorders and in acute leukemia. We studied the expression of CD200 in a series of 244 patients with diagnosis of acute myeloid leukemia (AML), to evaluate its impact on outcome and its possible association with other known prognostic factors.

CD200 was found in 136/244 (56\%) patients, in 41 of whom (30\%) with high intensity of expression (MFI $\geq 11$ ). CD200 was more frequent in secondary compared to de novo leukemia $(p=0.0006)$, in CD34 positive cases $(p=0.00001)$, in $\mathrm{BCl} 2$ overexpressing cases $(p=0.01)$, in those wild-type Flt3 $(p=0.004)$ and with favorable or unfavorable compared to intermediate karyotype $(p=0.0003)$. CD200+ patients have a two-fold lower probability to attain complete remission, both in univariate $(p=0.006)$ and multivariate $(p=0.04)$ analysis. The negative impact of CD200 was found also in overall survival $(p=0.02)$ and was correlated with the intensity of expression of the molecule $(p=0.024)$. CD200 has an additive negative impact on survival in patients with unfavorable cytogenetic $(p=0.046)$ and in secondary leukemia $(p=0.05)$, and is associate with a worsening of outcome in patients with favorable biological markers, such as mutated NPM $(p=0.02)$, wild-type FIt3 $(p=0.034)$, negativity of CD34 $(p=0.03)$ and of CD56 $(p=0.03)$.

In conclusion, CD200 is emerging as both a prognostic factor and a potential target of novel therapeutic approaches for AML, aiming to reverse the "do not eat me" signal of CD200 or to manipulate the suppressive immune microenvironment induced by CD200 binding to its receptor.

\section{INTRODUCTION}

Despite relatively high rates of complete remission (CR) with induction and consolidation chemotherapy, relapse occurs in the majority of adult patients with acute myeloid leukemia (AML), accounting for the poor likelihood of long-term survival. $[1,2]$

Besides clinical and laboratory features at diagnosis, such as age, performance status, tumor burden, antecedent hematological disorder or prior exposure to chemotherapy and extramedullary disease [3-6], various cytogenetic or molecular abnormalities are currently used for risk stratification $[7,8]$. The genetic features of AML, identifies in the last decades along with the understanding of leukemia biology, are pivotal to move towards a patienttailored therapy and follow-up. [9-13] However, to date only little improvement in survival rate has been observed, especially in high-risk patients, despite a wider use of stem cell transplantation (SCT), that is still considered the best consolidation therapy in poor-risk AML for the graftversus-leukemia action of allogeneic T- cells [14-19].

Given these premises, it is clear that mechanisms by which tumor cells can hamper immune recognition and survive in a permissive microenvironment should 
be taken into account. CD200 is a type- 1 membrane glycoprotein containing two immunoglobulin domains, normally expressed in a broad range of cells. [20] Its binding with CD200R is able to induce an immunosuppressive signal and, in animal models, favors the tumor growth [21-25]. In hematological malignancies CD200 expression was first reported in chronic lymphocytic leukemia, where it has a role in differential diagnosis with mantle cell lymphoma [26]. Lack of CD200 expression in plasma cells has been associated with more aggressive multiple myeloma. [27] More recently CD200 aberrant expression has been proposed as an adverse prognostic factor in AML. [28]

Since the relative paucity of data and the somehow conflicting results, aim of our study is to assess the pattern of CD200 expression in a series of adult patients with AML, its association with other known prognostic factors and the possible impact on clinical outcomes.

\section{PATIENTS AND METHODS}

Two hundred forty-four patients with diagnosis of non-promyelocytic AML admitted at the Divisions of Hematology of Udine and Siena between January 2008 and June 2014 were included in the study. Clinical and biological characteristics at diagnosis are summarized in Table 1. Diagnosis was performed on bone marrow smears according to FAB classification. [29] Cytogenetic risk was classified according to MRC criteria [30]. Flt3 and NPM mutations were evaluated as previously described. [31,32] Combined molecular and cytogenetic risk was assigned according to Döhner. [9]

Blast cells immunophenotype was evaluated by multiparametric flow cytometry (Facs Diva II, BD). CD200 aberrant presence on blast cells was tested using PE anti-human CD200- antibody (BD Pharmingen, Brussels, Belgium) and expressed as the percentage of positive cells (with $20 \%$ as cut-off value) and as the mean fluorescence intensity (MFI) obtained by the ratio of fluorescence intensity of the test and of its isotypic control. Cases with a MFI $=1$ were considered negative, patients with a MFI $<11$ as "low expressing" and case with MFI $\geq 11$ were considered as "high expressing".

Patients were treated according to Ethic Board approved Institutional protocols with induction chemotherapy and at least two consolidation courses after complete remission (CR). High-risk cases (defined as at least one of the following: secondary AML, poor response to induction chemotherapy, unfavorable cytogenetic or combined genetic risk, or patients with early relapse) underwent allogeneic stem cell transplantation (SCT) from related or unrelated donor. Poor performance status or elderly patients, deemed not suitable for intensive chemotherapy, received cytoreduction with hydroxyurea, low-dose cytarabine or oral 6-mercaptopurine.

\section{Definitions and statistical analysis}

Complete remission (CR) was defined as the complete peripheral hematological recovery and the absence of bone marrow disease (at morphological, immunophenotypic or molecular evaluation). Overall survival (OS) was calculated from diagnosis to death (irrespective from the cause). Leukemia free survival (LFS) was defined as the time between CR and relapse. Patients lost to follow up were censored at the time last seen alive.

Categorical variable were compared with Fisher exact test or Yates corrected chi square test, as required. Comparisons between continuous variables were evaluated by $\mathrm{T}$ student test or by Kruskall Wallis test. Factors affecting $\mathrm{CR}$ were assessed by univariate and multivariate logistic regression, and expressed as $\mathrm{HR}(95 \% \mathrm{CI})$. OS curves were constructed by Kaplan Meier method and differences among groups calculated by log-rank test. The Cox proportional hazard regression model was used to examine the potential prognostic factors for OS: all variables with $p$ values $\leq 0.10$ in univariate analysis were included in the multivariable model and a backward stepwise procedure was applied to identify significant factors. All $p$-values are 2-sided at a significance level of 0.05 . Statistics was performed by NCSS 10 Statistical Software (2015) ("NCSS, LLC. Kaysville, Utah, USA, http://ncss.com/software/ncss.").

\section{RESULTS}

Aberrant expression of CD200 was found in $136 / 244$ patients $(56 \%)$ with a mean MFI of 11 (range $2-100$ ). High intensity of expression (mean MFI $=23.5$ \pm 10 ) was detected in $41 / 136(30 \%)$ positive patients. As shown in Table 2, CD200 was more frequently expressed in secondary leukemia $(52 / 71,73 \%)$, compared to de novo $(84 / 172,49 \% ; p=0.0006)$, while no association was found with age, WBC count at diagnosis and $\mathrm{FAB}$ subtype. However CD200 was more frequently expressed in CD34 positive blast cells $(p<0.00001)$ and in patients with high levels of $\operatorname{Bcl} 2(p=0.01)$, while there was an inverse correlation with CD56 expression (39/87, 45\% in CD56+ vs $95 / 154,62 \%$ in CD56 negative patients; $p=0.015$ ).

High frequency of CD200 expression was detectable in patients without Flt3-ITD mutation (105/170, 62\%) compared to patients with Flt3-ITD mutation (17/46, $37 \%, p=0.004)$ and in patients with wild type NPM $(99 / 145,68 \%)$ vs those with mutated NPM $(19 / 65,29 \%$, $p=0.0013)$.

Considering karyotype, a lower frequency of CD200 positivity was found in intermediate cytogenetic group $(65 / 139,47 \%)$, compared to favorable $(13 / 14$, $93 \%)$ and unfavorable risk group $(44 / 67,66 \% ; p=$ 0.0003 ), and in the favorable or intermediate groups of the combined cytogenetic/molecular classification 
Table 1: Clinical/biological characteristics at diagnosis

\begin{tabular}{|c|c|}
\hline & n. 244 \\
\hline $\begin{array}{l}\text { Età Median (range) yrs } \\
\text { Età } \geq 55\end{array}$ & $\begin{array}{c}59(18-84) \\
147\end{array}$ \\
\hline Sex: M/F & $173 / 71$ \\
\hline $\begin{array}{l}\text { WBCx } 10^{9} / \mathrm{L}: \text { mean } \pm 2 \text { SD } \\
\mathrm{WBC} \geq 30 \times 10^{9} / \mathrm{L}\end{array}$ & $\begin{array}{c}13.9 \pm 42.5 \\
98(40 \%)\end{array}$ \\
\hline $\begin{array}{r}\text { Type of leukemia : De novo } \\
\text { Secondary }\end{array}$ & $\begin{array}{l}173(71 \%) \\
71(29 \%)\end{array}$ \\
\hline $\begin{array}{r}\text { FAB (de novo): } \text { M0 } \\
\text { M1 } \\
\text { M2 } \\
\text { M4 } \\
\text { M5 } \\
\text { M6 }\end{array}$ & $\begin{array}{l}10(6 \%) \\
32(18 \%) \\
28(16 \%) \\
35(20 \%) \\
65(38 \%) \\
3(2 \%)\end{array}$ \\
\hline $\begin{array}{l}\text { Combined cytogenetic/molecular risk: } \\
\text { Favorable } \\
\text { Int-1 } \\
\text { Int-2 } \\
\text { Unfavorable } \\
\text { NA }\end{array}$ & $\begin{array}{l}43(18 \%) \\
61(25 \%) \\
35(14 \%) \\
70(29 \%) \\
35(14 \%)\end{array}$ \\
\hline $\begin{array}{l}\text { Flt3-ITD: mutated } \\
\text { wild type } \\
\text { NA }\end{array}$ & $\begin{array}{c}46(19 \%) \\
170(70 \%) \\
28(11 \%)\end{array}$ \\
\hline $\begin{array}{l}\text { NPM: mutated } \\
\text { wild type } \\
\text { NA }\end{array}$ & $\begin{array}{c}65(27 \%) \\
145(59 \%) \\
34(14 \%)\end{array}$ \\
\hline $\begin{array}{l}\text { Cytogenetic risk: } \\
\text { Favorable } \\
\text { Intermediate } \\
\text { Unfavorable } \\
\text { NA }\end{array}$ & $\begin{array}{c}14(6 \%) \\
136(56 \%) \\
70(29 \%) \\
24(10 \%)\end{array}$ \\
\hline $\begin{array}{r}\text { CD34: positive } \\
\text { negative }\end{array}$ & $\begin{array}{l}130(53 \%) \\
114 / 47 \%)\end{array}$ \\
\hline $\begin{array}{c}\text { CD56: positive } \\
\text { Negative } \\
\text { NA }\end{array}$ & $\begin{array}{c}87(36 \%) \\
154(63 \%) \\
3(1 \%)\end{array}$ \\
\hline Bcl2-MFI: $\begin{aligned} & \geq 17 \\
& <17 \\
& \text { NA }\end{aligned}$ & $\begin{array}{c}124(51 \%) \\
113(46 \%) \\
7(3 \%)\end{array}$ \\
\hline
\end{tabular}

$(74 / 150,49 \%)$ compared to the unfavorable $(48 / 69,69 \%$; $p=0.02)$.

\section{CD200 and response to induction therapy}

One hundred forty-nine out of 244 (61\%), obtained CR, 10/244 (4\%) died during induction and $85 / 244$ (35\%) were resistant to induction therapy. Relapse occurred in 54/149 (36\%) patients at a median of 30 months.
Factors affecting CR probability are listed in Table 3. In univariate analysis, age higher than 55 years $(p<$ $0.00001)$, secondary disease $(p<0.00001)$, CD34 positivity $(p=0.0001)$ and unfavorable cytogenetics $(p=0.01)$ or unfavorable molecular/cytogenetic status $(p=0.00001)$ were associated with reduced probability to achieve CR. CR was obtained in 73/130 (56\%) in CD200+ and in 76/100 CD200- $(76 \%)$ evaluable patients $(p=0.006)$. Patients with aberrant CD200 expression have almost two fold less probability to obtain $\mathrm{CR}(\mathrm{OR}=0.45,95 \% \mathrm{CI}$ : $0.26-0.80)$. 
Table 2: CD200 and clinical/biological characteristics at diagnosis

\begin{tabular}{|c|c|c|}
\hline & CD200+ & $P$ \\
\hline $\begin{aligned} \text { Age: } & \geq 55 \text { yrs } \\
& <55 \text { yrs }\end{aligned}$ & $\begin{array}{c}84 / 147(57 \%) \\
53 / 97(55 \%)\end{array}$ & 0.79 \\
\hline $\begin{array}{r}\text { Type of leukemia : De novo } \\
\text { Secondary }\end{array}$ & $\begin{array}{c}84 / 172(49 \%) \\
52 / 71(73 \%)\end{array}$ & 0.0006 \\
\hline $\begin{aligned} \text { Cytotype: } & \text { M0 } \\
& \text { M1-M2 } \\
& \text { M4-M5 } \\
& \text { M6 }\end{aligned}$ & $\begin{array}{c}7 / 16(43 \%) \\
35 / 65(54 \%) \\
56 / 111(50 \%) \\
1 / 3(33 \%)\end{array}$ & 0.8 \\
\hline $\begin{aligned} \text { WBC: }: & \geq 30 \times 10^{9} / \mathrm{L} \\
& <30 \times 10^{9} / \mathrm{L}\end{aligned}$ & $\begin{array}{c}48 / 99(48 \%) \\
87 / 145(60 \%)\end{array}$ & 0.08 \\
\hline $\begin{aligned} \text { Cytogenetic: } & \text { Favorable } \\
& \text { Intermediate } \\
& \text { Unfavorable }\end{aligned}$ & $\begin{array}{c}13 / 14(93 \%) \\
65 / 139(47 \%) \\
44 / 67(66 \%)\end{array}$ & 0.0003 \\
\hline $\begin{array}{r}\text { Flt3-ITD: Positive } \\
\text { Negative }\end{array}$ & $\begin{array}{c}17 / 46(37 \%) \\
105 / 170(62 \%)\end{array}$ & 0.004 \\
\hline $\begin{array}{c}\text { NPM: Wild type } \\
\text { Mutate }\end{array}$ & $\begin{array}{c}99 / 145(68 \%) \\
19 / 65(29 \%)\end{array}$ & 0.0013 \\
\hline 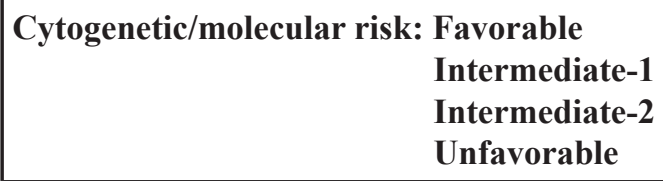 & $\begin{array}{l}23 / 44(52 \%) \\
31 / 70(44 \%) \\
20 / 36(55 \%) \\
48 / 69(69 \%)\end{array}$ & 0.02 \\
\hline $\begin{array}{r}\text { CD34: Positive } \\
\text { Negative }\end{array}$ & $\begin{array}{l}99 / 129(77 \%) \\
36 / 113(32 \%)\end{array}$ & $<0.00001$ \\
\hline $\begin{array}{r}\text { CD56: Positive } \\
\text { Negative }\end{array}$ & $\begin{array}{c}39 / 87(45 \%) \\
95 / 154(62 \%)\end{array}$ & 0.015 \\
\hline Bcl2 MFI: $\begin{aligned} & \geq 17 \\
& <17\end{aligned}$ & $\begin{array}{l}65 / 101(64 \%) \\
66 / 136(48 \%)\end{array}$ & 0.01 \\
\hline
\end{tabular}

The negative impact of CD200 on remission probability was maintained in multivariate analysis $(p=0.04)$, along with more conventional factors such as age $(p=0.002)$, type of leukemia $(p=0.002)$, CD34 positivity $(p=0.008)$ and unfavorable cytogenetic risk $(p=0.0025)$ (Table 3).

\section{Overall survival}

At the time of analysis $101 / 244$ patients (41\%) were alive without evidence of disease, with a 3 -year survival probability of 37\% (95\%CI: 29-43). Threeyear OS was significantly reduced in patients aged $\geq$ 55 years compared to younger patients $(21 \%$ vs $60 \%$, $p<0.0001)$, in case of secondary AML (20\% vs $43 \%$ in de novo leukemia, $p=0.0004)$, and in CD34 positive cases $(23 \%$, vs $53 \%$ in CD34- patients, $p<0.0001)$. As expected, unfavorable karyotype was associated with poorer survival (3-year OS $22 \%$, compared to $40 \%$ in normal/intermediate and $60 \%$ in favorable cytogenetic, $p=0.0003)$. No impact on OS was also observed for Flt3-ITD, both in the whole population and in the normal/intermediate cytogenetic subgroup. Conversely the presence of a NPM mutation conferred a survival advantage irrespective to karyotype with a 3-year OS $50 \%$ in mutated vs $33 \%$ in WT $(p=0.01)$. Considering the combined cytogenetic/molecular risk, OS in the unfavorable group (30\% at 3 years) was significantly lower compared with the other risk groups $(58 \%$ in favorable, $43 \%$ in intermediate- $1,34 \%$ intermediate- 2 ; $p=0.0001)$. With regard of CD200, OS was negatively affected by both aberrant molecule expression (3-year OS $31 \%$ vs $45 \% ; p=0.02$, Figure $1 \mathrm{a})$, and by intensity of expression ( $17 \%$ in patients with high MFI compared to $36 \%$ in those with low intensity of expression; $p=$ 0.024) (Figure 1b).

In multivariate analysis (Table 4), advanced age $(\mathrm{HR}=0.46,95 \% \mathrm{CI} 0.30-0.69)$, unfavorable cytogenetic $(\mathrm{HR}=0.33,95 \% \mathrm{CI} 0.13-0.79), \mathrm{CD} 34$ positivity (HR 0.44, 95\%CI 0.29-0.67) and CD200 
Table 3: Uni and multivariate analysis of potential factors for CR

\begin{tabular}{l|c|c|c|c|}
\hline \multicolumn{5}{c}{ Univariate } \\
\hline ORe $\geq \mathbf{5 5}$ yrs & $0.23(0.12-0.43)$ & $<0.00001$ & $0.40(0.19-0.87)$ & Multivariate \\
\hline WBC $\geq \mathbf{3 0} \times \mathbf{1 0} \%$ & $0.6(0.36-1-11)$ & 0.1 & 0.0019 \\
\hline Secondary leukemia & $0.19(0.10-0.35)$ & $<0.00001$ & $0.31(0.15-0.65)$ & 0.0019 \\
\hline $\begin{array}{l}\text { Unfavorable } \\
\text { Cytogenetic }\end{array}$ & $0.08(0.005-0.61)$ & 0.01 & \\
\hline $\begin{array}{l}\text { Unfavorable } \\
\text { Cytogenetic/ } \\
\text { molecular }\end{array}$ & $0.07(0.025-0.24)$ & 0.00001 & $0.12(0.03-0.47)$ & 0.0025 \\
\hline NPM unmutated & $0.26(0.12-0.55)$ & 0.0004 & & \\
\hline CD34 positive & $0.27(0.15-0.48)$ & 0.0001 & & 0.008 \\
\hline CD56 positive & $0.74(0.42-1.30)$ & 0.27 & $0.36(0.17-0.77)$ & \\
\hline CD200 positive & $0.52(0.29-0.91)$ & 0.02 & & \\
\hline CD200 MFI $\geq 11$ & $0.41(0.19-0.92)$ & 0.03 & & \\
\hline Bcl-2 MFI $\geq \mathbf{1 7}$ & $0.78(0.45-1.35)$ & 0.38 & & \\
\hline
\end{tabular}
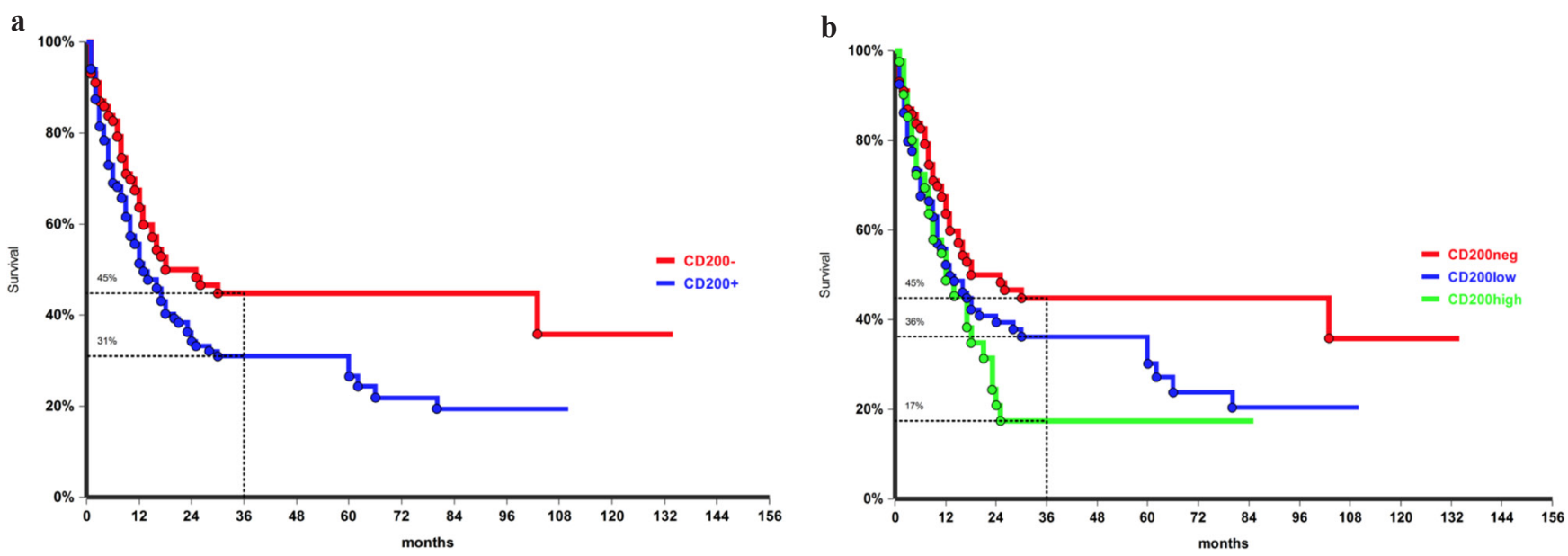

Figure 1: Overall survival of the entire population according to CD200 expression, $p=0.02$, a. and by CD200 intensity of expression, $p=0.024$, b. CD200 negative: MFI = 1; CD200 low: MFI < 11; CD200 high: MFI $\geq 11$.

$\mathrm{MFI} \geq 11(\mathrm{HR} 0.57,95 \% \mathrm{CI} 0.32-0.97)$ retained their negative prognostic role.

\section{Association of CD200 with other prognostic factors and outcome}

We then evaluated the impact of the expression of CD200 in different biologically/molecularly defined prognostic groups.

Patients with unfavorable karyotype expressing CD200 have a survival rate significantly lower than CD200 negative patients (3-year OS 11\% vs 39\%, $p=0.046$ ) (Figure 2a). We found a trend for a lower OS according to CD200 intensity of expression: 3-year survival rate was $18 \%$ in CD200low compared to $0 \%$ in CD200-high expressing patients (Figure 2b). A worse survival was observed also in patients with favorable cytogenetic and high CD200 expression (33\%) compared to those CD200-low (79\%). The lack of statistical significance is probably due to the small size of the two groups. Instead, CD200 positivity did not influence survival probability in the intermediate cytogenetic risk.

Considering Flt3, co-expression of CD200 did not worsen survival probability in Flt3-ITD+ patients, but negatively affected survival in ITD-negative patients; 3 -year OS was 42\% in CD200-, 36\% in CD200-low and $0 \%$ in CD200-high patients ( $p=0.034$, Figure $3 a$ ). 
Table 4: multivariate analysis of factors for OS

\begin{tabular}{|l|c|c|}
\hline \multicolumn{2}{|c|}{ HR $(\mathbf{9 5} \% \mathbf{C I})$} & \multicolumn{1}{c}{0.0002} \\
\hline Age $\geq \mathbf{5 5}$ yrs & $0.46(0.30-0.69)$ & 0.78 \\
\hline Unfavorable cytogenetic risk & $0.92(0.61-1.39)$ & 0.01 \\
\hline CD34 positivity & $0.33(0.13-0.79)$ & 0.0002 \\
\hline CD200 MFI $\geq \mathbf{1 1}$ & $0.44(0.29-6.67)$ & 0.04 \\
\hline
\end{tabular}
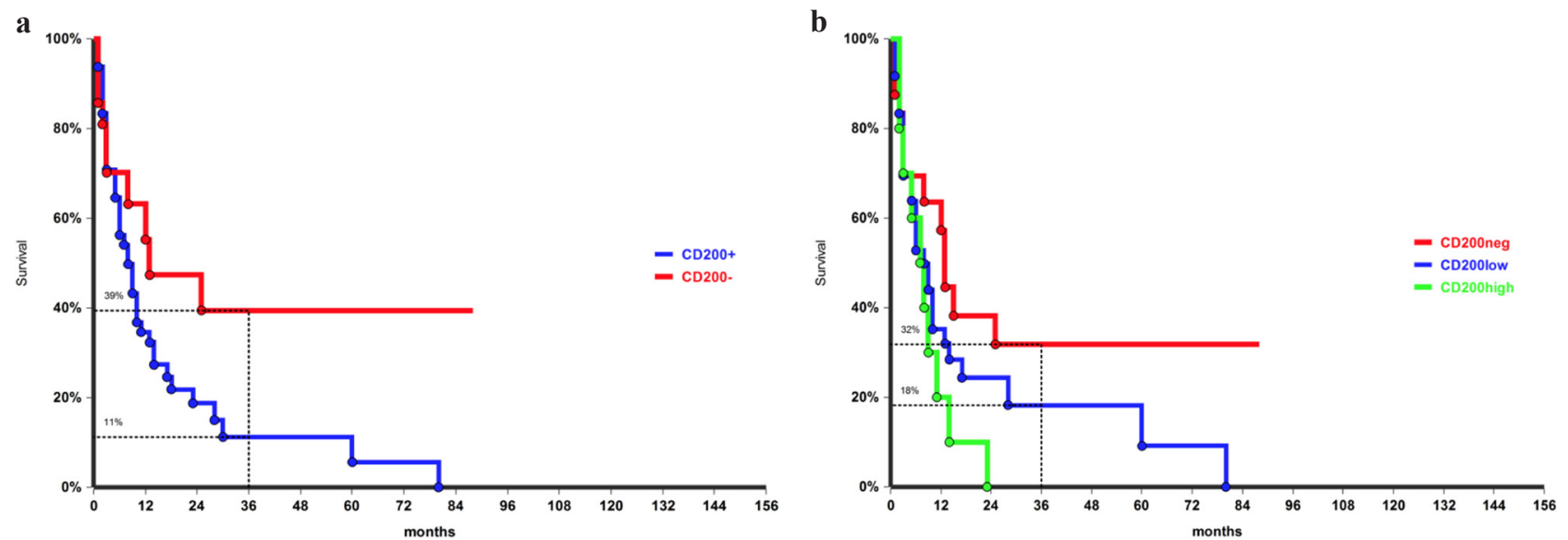

Figure 2: Overall survival in patients with unfavorable cytogenetics: difference in CD200 negative and in CD200 positive patients, $p=0.046$, a. and according to CD200 MFI, $p=0.06, b$.

a

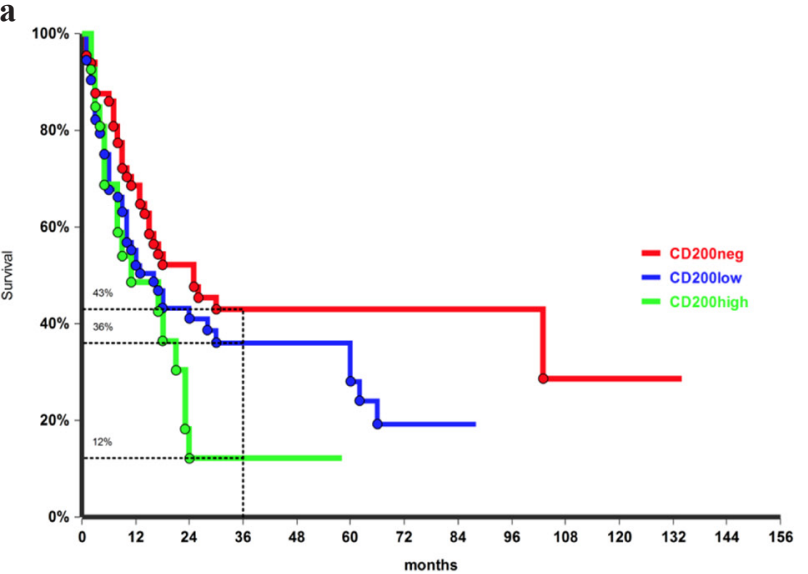

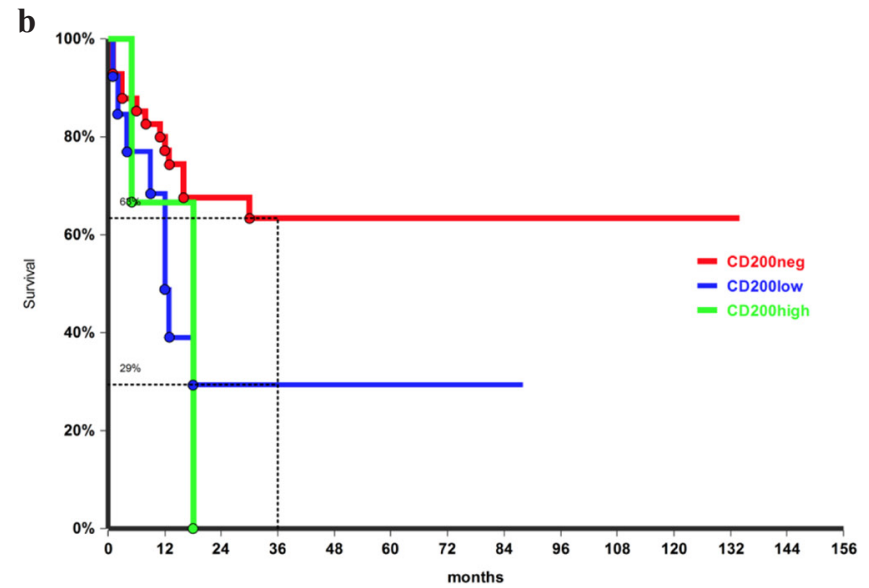

Figure 3: Overall survival by CD200 intensity of expression in patients FLT3-ITD negative $p=0.034$, a. and in NPM mutated group, $p=0.02, b$.

In NPM mutated patients CD200 was less frequent than in NPM WT ones, but, when present, CD200+/NPM mutated cases had a lower OS rate compared to their CD200- counterpart (3-year OS 63\% vs 25\%, $p=0.02$, Figure $3 b)$. In NPM-WT patients 3 -year OS was $29 \%$ in CD200+ and $37 \%$ in CD200- cases $(p=0.1)$.

No difference in survival probability was found according to CD200 status in CD56+ patients. Conversely in CD56- AML, CD200 expression was associated with a lower survival probability: 3 -year OS was $57 \%$ in CD200-, 35\% in CD200-low and 0\% in CD200-high patients $(p=0.03$; Figure 4a). As for CD56, no impact on survival was observed for CD200 in CD34+ patients, while in the CD34-negative group CD200 high was associated with worse 3-year OS probability: 0\% compared with 59\% in CD200 low and 57\% in CD200 negative patients ( $p=0.03$, Figure $4 b$ ).

Last, CD200 had a negative impact on OS in both de novo and in secondary AML. At 3-year, in de novo cohort OS was $49 \%$ in CD200- and 35\% in CD200+ patients $(p=0.04$; Figure 5a). In secondary AML 3-year 

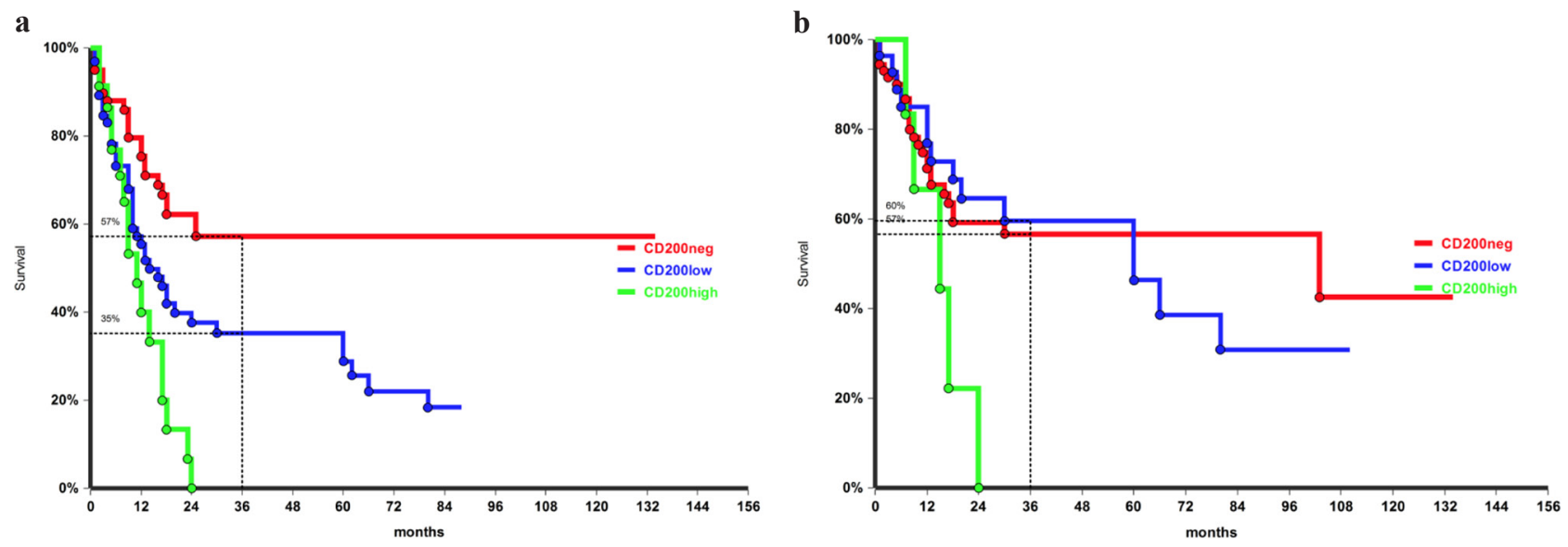

Figure 4: Overall survival according to CD200 MFI in CD56 negative patients, $p=0.04$, a. and in CD34 negative patients, $p=0.03, b$.
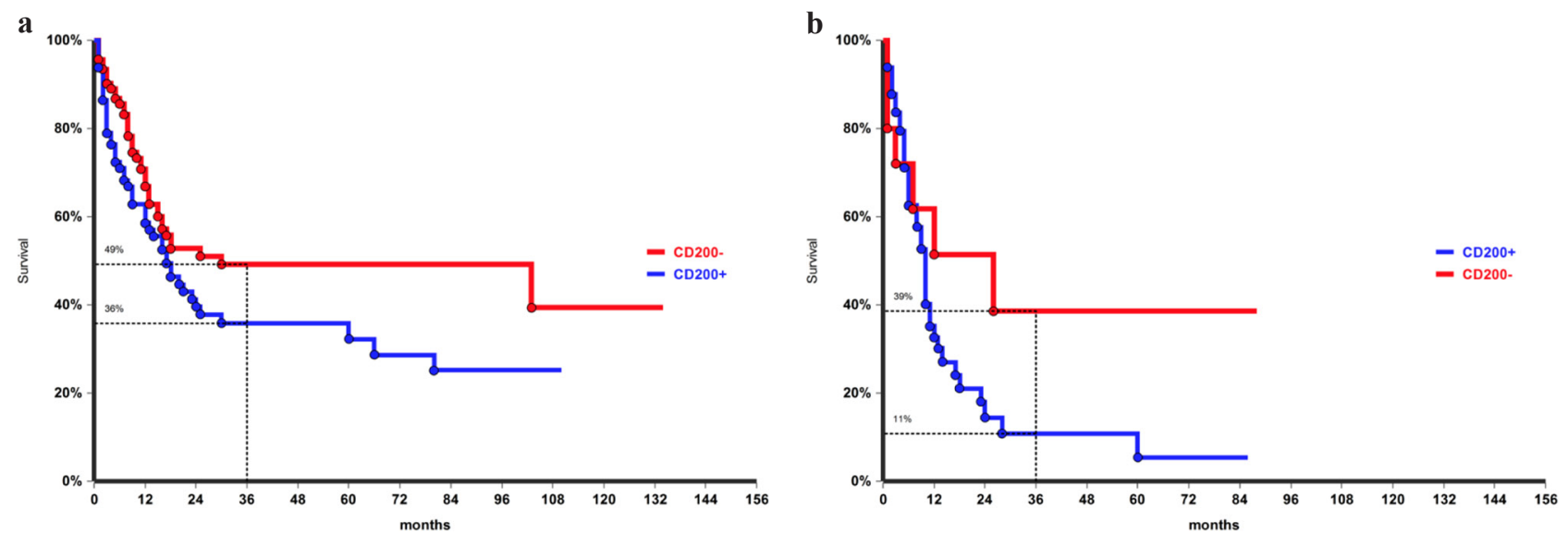

Figure 5: Overall survival by CD200 expression in de novo, $p=0.04$ a. and secondary leukemia, $p=0.05$ b.

OS was $38 \%$ in $\mathrm{CD} 200$ - and $16 \%$ in $\mathrm{CD} 200+(p=0.05$; Figure 5b).

\section{DISCUSSION}

Along with factors promoting drug resistance or favoring neoplastic cells' escape from programmed death, the mechanisms by which AML can evade immunosurveillance have recently gained new attention. Many ways are employed by leukemic cells to escape recognition and destruction by immune effector cells, such as down-regulation of HLA molecules, secretion of inhibitory cytokines, recruitment of tolerogenic cells, modification of costimulatory and co-inhibitory signals. In the present paper we focused on the potential impact of CD200 expression on outcome of a series of 244 adult patients with non-promyelocytic AML. We found an aberrant expression of CD200 in 56\% of cases, with a high intensity of expression in 30\%. Differently from what has been reported by Tonks at al [28] we did not find differences in $\mathrm{CD} 200$ expression among FAB subtypes, but in our series 77\% of CD34-positive expressed also CD200. Many authors reported an association between CD200 and stem cell properties in solid tumors [33-35], suggesting that cancer stem cells use CD200 system to prevent the attack of the immune system. In our cases we did not find association with other marker of leukemic stemness. As in the work by Tonks et al. [28], aberrant CD200 expression was detected in the vast majority (93\%) of AML cases with favorable cytogenetic, but we found high rate of CD200 positivity also in patients with unfavorable katyotype $(P=0.0003)$, NPM1 wild type $(P=0.001)$, Flt3-ITD negative $(P=0.004)$, and with unfavorable cytogenetic/molecular status, as recently defined by Döhner [9] $(P=0.02)$. Moreover CD200 was more frequently expressed secondary than in de novo leukemia ( $73 \%$ vs $49 \%$ ).

CD200 positivity was associated with lower rates of complete remission and survival, as confirmed in multivariable analysis. Tonks and coworkers [28] found a negative impact on survival in the whole population and the subgroup with core binding factor AML. Analyzing survival in the different cytogenetic risk groups, we found a negative impact of CD200 expression in patients with unfavorable karyotype, while in cases with CBF alterations the lack of significance is probably due to the limited number of patients. 
Interestingly, CD200 seemed to worsen survival in NPM mutated and in Flt3-ITD wild type patients, irrespectively of karyotype, so identifying a subset of patients with poor prognosis in a group usually associated with a more favorable outcome. A negative impact on OS was observed also in CD56 negative patients, that are usually considered to have a better prognosis compared to CD56+ patient. [36-38] Conversely, no differences in OS probability are evident evaluating CD200 and CD34 expression. It could be speculated that CD200 in CD34+ leukemic cell resembles the normal expression on $\mathrm{CD} 34+$ progenitors, where it contributes in protection from auto-aggression by the immune system cells. Despite the different rate of expression in de novo and secondary AML, CD200 expression had a negative impact on OS in both groups; 3-year survival in CD200+ de novo cases $(36 \%)$ was similar to that of CD200- secondary AML (39\%), and significantly lower than CD200- de novo (49\%) but higher than CD200+ secondary (11\%) patients, respectively. So, the combination of CD200 expression and leukemia type define three group of patients with significant different survival expectation $(p=0,0007)$.

Mechanisms by which CD200 exerts its negative influence on outcome are only partially defined. In the recent years the complex network connecting innate and adaptive immune cells to response to foreign pathogens, to self-antigens and to tumor cells begin to clarify, and their identification may contribute to the design of novel target therapies. Coles et al. observed a suppression of memory T-cells and a reduction of NK activity in CD200 positive AML patients, especially in the NK cells with high lytic activity $[39,40]$. We did not find a significant reduction in NK populations in our population, but T-cells were studied on in a minority of cases, thus we cannot confirm the observation of an increased frequency of CD4+ regulatory cell and a recovery of Th1 response by Tregs depletion in CD200-positive leukemia [41]. In line with this findings, Memarian et al. reported high levels of IL10 production in autologous mixed lymphocyte reactions in presence of AMLdendritic cells [42]. Coles and coworkers have hypothesized a co-operation between CD200/CD200R and PD-L1/PD-1 axis as a cause of the worse prognosis linked to overexpression of CD200 and PD-L1 on leukemic blast cells [43].

In our series, preliminary data indicate a higher occurrence of myeloid-derived suppressor cells (MDSC), that are known to play a central role in regulating immune response and tumor tolerance [21, 44-46], in CD200 positive patients. Similar findings have been reported by Moertel et al. in human brain tumors [47]. They found that high levels of CD200 correlated with MDSC expansion and demonstrated, in an experimental model, that the block of CD200/CD200R prevents MDSC induction and inactivates the release of inhibitory cytokines. If confirmed, our data may be of interest not only for prognosis but also for the pathogenesis of AML. Chen et al have reported a role of MDSC in inducing multilineage cytopenia and cytological dysplasia [48].
In conclusion, our study confirms the negative prognostic role of CD200 in AML and identifies subgroups of patients in which CD200 significantly reduces survival probability. Of note, beside an additive negative impact in patients with unfavorable cytogenetic or secondary AML, CD200 overexpression is associated with a worse prognosis also in patients with biological markers considered favorable, such as mutated NPM, Flt3 wild type, negativity of CD34 and CD56 expression and, probably, CBF AML. Taken together, these findings can be useful in the management of AML patients. Novel therapeutic approaches could be designed in order to manipulate the immune microenvironment, reversing the "do not eat me signal" of CD200. Anti-CD200 antibodies have demonstrated in vitro efficacy [49] and are under investigation in chronic lymphocytic leukemia [50]. Moreover many drugs able to deactivate MDSC [51, $52]$, to block their development $[53,54]$ or to deplete them $[54,55]$ have been developed in the last years and will probably deeply change the therapeutic scenarios of hematologic malignancies.

\section{CONFLICTS OF INTEREST}

None.

\section{REFERENCES}

1. Tallman MS, Gilliland DG, Rowe JM. Drug therapy for acute myeloid leukemia. Blood. 2005; 106:1154-1163.

2. Pulte D, Gondos A, Brenner H. Improvements in survival of adults diagnosed with acute myeloblastic leukemia in the early 21 st century. Haematologica. 2008; 93:594-600.

3. Greenwood MJ, Seftel MD, Richardson C, Barbaric D, Barnett MJ, Bruyere H, Forrest DL, Horsman DE, Smith C, Song K, Sutherland HJ, Toze CL, Nevill TJ, Nantel SH, Hogge DE. Leukocyte count as a predictor of death during remission induction in acute myeloid leukemia. Leukemia \& lymphoma. 2006; 47:1245-1252.

4. Dalley CD, Lister TA, Cavenagh JD, Rohatiner AZ. Serum $\mathrm{LDH}$, a prognostic factor in elderly patients with acute myelogenous leukaemia. British journal of cancer. 2001; 84:147.

5. Larson RA. Is secondary leukemia an independent poor prognostic factor in acute myeloid leukemia? Best practice \& research Clinical haematology. 2007; 20:29-37.

6. Smith ML, Hills RK, Grimwade D. Independent prognostic variables in acute myeloid leukaemia. Blood reviews. 2011; 25:39-51.

7. Grimwade D, Walker H, Oliver F, Wheatley K, Harrison C, Harrison G, Rees J, Hann I, Stevens R, Burnett A, Goldstone A. The importance of diagnostic cytogenetics on outcome in AML: analysis of 1,612 patients entered into the MRC AML 10 trial. The Medical Research Council Adult and Children's Leukaemia Working Parties. Blood. 1998; 92:2322-2333. 
8. Schlenk RF, Dohner K, Krauter J, Frohling S, Corbacioglu A, Bullinger L, Habdank M, Spath D, Morgan M, Benner A, Schlegelberger B, Heil G, Ganser A, Dohner H GermanAustrian Acute Myeloid Leukemia Study G. Mutations and treatment outcome in cytogenetically normal acute myeloid leukemia. The New England journal of medicine. 2008; 358:1909-1918.

9. Dohner H, Estey EH, Amadori S, Appelbaum FR, Buchner T, Burnett AK, Dombret H, Fenaux P, Grimwade D, Larson RA, Lo-Coco F, Naoe T, Niederwieser D, Ossenkoppele GJ, Sanz MA, Sierra J, et al. Diagnosis and management of acute myeloid leukemia in adults: recommendations from an international expert panel, on behalf of the European LeukemiaNet. Blood. 2010; 115:453-474.

10. Estey E. Recent developments in management of older patients with acute myeloid leukemia. Therapeutic advances in hematology. 2012; 3:89-96.

11. Hokland P, Ommen HB. Towards individualized follow-up in adult acute myeloid leukemia in remission. Blood. 2011; 117:2577-2584.

12. Wolach O, Stone RM. Is it time to change conventional consolidation chemotherapy for acute myeloid leukemia in CR1? Current opinion in hematology. 2015; 22:123-131.

13. Estey EH. Acute myeloid leukemia: 2014 update on riskstratification and management. American journal of hematology. 2014; 89:1063-1081.

14. Koreth J, Schlenk R, Kopecky KJ, Honda S, Sierra J, Djulbegovic BJ, Wadleigh M, DeAngelo DJ, Stone RM, Sakamaki H, Appelbaum FR, Dohner H, Antin JH, Soiffer RJ, Cutler C. Allogeneic stem cell transplantation for acute myeloid leukemia in first complete remission: systematic review and meta-analysis of prospective clinical trials. Jama. 2009; 301:2349-2361.

15. Jabbour E, Daver N, Champlin R, Mathisen M, Oran B, Ciurea S, Khouri I, Cornelison AM, Ghanem H, Cardenas-Turanzas M, Popat U, Ravandi F, Giralt S, Garcia-Manero G, Cortes J, Kantarjian H, et al. Allogeneic stem cell transplantation as initial salvage for patients with acute myeloid leukemia refractory to high-dose cytarabine-based induction chemotherapy. American journal of hematology. 2014; 89:395-398.

16. Forman SJ, Rowe JM. The myth of the second remission of acute leukemia in the adult. Blood. 2013; 121:1077-1082.

17. Damiani D, Tiribelli M, Geromin A, Cerno M, Sperotto A, Toffoletti E, Simeone E, Michelutti A, Cavallin M, Fanin R. Donor compatibility and performance status affect outcome of allogeneic haematopoietic stem cell transplant in patients with relapsed or refractory acute myeloid leukaemia. Annals of hematology. 2012; 91:1937-1943.

18. Burnett AK, Goldstone A, Hills RK, Milligan D, Prentice A, Yin J, Wheatley K, Hunter A, Russell N. Curability of patients with acute myeloid leukemia who did not undergo transplantation in first remission. Journal of clinical oncology : official journal of the American Society of Clinical Oncology. 2013; 31:1293-1301.
19. Gale RP, Wiernik PH, Lazarus HM. Should persons with acute myeloid leukemia have a transplant in first remission?. Leukemia. 2014; 28:1949-1952.

20. Barclay AN, Clark MJ, McCaughan GW. Neuronal/lymphoid membrane glycoprotein MRC OX-2 is a member of the immunoglobulin superfamily with a light-chain-like structure. Biochemical Society symposium. 1986; 51:149-157.

21. Rygiel TP, Meyaard L. CD200R signaling in tumor tolerance and inflammation: A tricky balance. Current opinion in immunology. 2012; 24:233-238.

22. Rygiel TP, Karnam G, Goverse G, van der Marel AP, Greuter MJ, van Schaarenburg RA, Visser WF, Brenkman AB, Molenaar R, Hoek RM, Mebius RE, Meyaard L. CD200-CD200R signaling suppresses antitumor responses independently of CD200 expression on the tumor. Oncogene. 2012; 31:2979-2988.

23. Gorczynski RM, Chen Z, Diao J, Khatri I, Wong K, Yu K, Behnke J. Breast cancer cell CD200 expression regulates immune response to EMT6 tumor cells in mice. Breast cancer research and treatment. 2010; 123:405-415.

24. Gorczynski RM, Chen Z, Hu J, Kai Y, Lei J. Evidence of a role for CD200 in regulation of immune rejection of leukaemic tumour cells in C57BL/6 mice. Clinical and experimental immunology. 2001; 126:220-229.

25. Gorczynski RM, Clark DA, Erin N, Khatri I. Role of CD200 expression in regulation of metastasis of EMT6 tumor cells in mice. Breast cancer research and treatment. 2011; 130:49-60.

26. Palumbo GA, Parrinello N, Fargione G, Cardillo K, Chiarenza A, Berretta S, Conticello C, Villari L, Di Raimondo F. CD200 expression may help in differential diagnosis between mantle cell lymphoma and B-cell chronic lymphocytic leukemia. Leukemia research. 2009; 33:1212-1216.

27. Alapat D, Coviello-Malle J, Owens R, Qu P, Barlogie B, Shaughnessy JD, Lorsbach RB. Diagnostic usefulness and prognostic impact of CD200 expression in lymphoid malignancies and plasma cell myeloma. American journal of clinical pathology. 2012; 137:93-100.

28. Tonks A, Hills R, White P, Rosie B, Mills KI, Burnett AK, Darley RL. CD200 as a prognostic factor in acute myeloid leukaemia. Leukemia. 2007; 21:566-568.

29. Bennett JM, Catovsky D, Daniel MT, Flandrin G, Galton DA, Gralnick HR, Sultan C. Proposals for the classification of the acute leukaemias. French-American-British (FAB) co-operative group. British journal of haematology. 1976; 33:451-458.

30. Grimwade D, Hills RK, Moorman AV, Walker H, Chatters S, Goldstone AH, Wheatley K, Harrison CJ, Burnett AK National Cancer Research Institute Adult Leukaemia Working G. Refinement of cytogenetic classification in acute myeloid leukemia: determination of prognostic significance of rare recurring chromosomal abnormalities among 5876 younger adult patients treated in the United Kingdom Medical Research Council trials. Blood. 2010; 116:354-365. 
31. Noguera NI, Breccia M, Divona M, Diverio D, Costa V, De Santis S, Avvisati G, Pinazzi MB, Petti MC, Mandelli F, Lo Coco F. Alterations of the FLT3 gene in acute promyelocytic leukemia: association with diagnostic characteristics and analysis of clinical outcome in patients treated with the Italian AIDA protocol. Leukemia. 2002; 16:2185-2189.

32. Pianta A, Fabbro D, Damiani D, Tiribelli M, Fanin R, Franzoni A, Romanello M, Tell G, Di Loreto C, Damante G. Two novel NPM1 mutations in a therapy-responder AML patient. Hematological oncology. 2010; 28:151-155.

33. Moreaux J, Veyrune JL, Reme T, De Vos J, Klein B. CD200: a putative therapeutic target in cancer. Biochemical and biophysical research communications. 2008; 366:117-122.

34. Kawasaki BT, Mistree T, Hurt EM, Kalathur M, Farrar WL. Co-expression of the toleragenic glycoprotein, CD200, with markers for cancer stem cells. Biochemical and biophysical research communications. 2007; 364:778-782.

35. Kawasaki BT, Farrar WL. Cancer stem cells, CD200 and immunoevasion. Trends in immunology. 2008; 29:464-468.

36. Raspadori D, Damiani D, Lenoci M, Rondelli D, Testoni N, Nardi G, Sestigiani C, Mariotti C, Birtolo S, Tozzi M, Lauria F. CD56 antigenic expression in acute myeloid leukemia identifies patients with poor clinical prognosis. Leukemia. 2001; 15:1161-1164.

37. Raspadori D, Damiani D, Michieli M, Stocchi R, Gentili S, Gozzetti A, Masolini P, Michelutti A, Geromin A, Fanin R, Lauria F. CD56 and PGP expression in acute myeloid leukemia: impact on clinical outcome. Haematologica. 2002; $87: 1135-1140$.

38. Junca J, Garcia-Caro M, Granada I, Rodriguez-Hernandez I, Torrent A, Morgades M, Ribera JM, Milla F, Feliu E. Correlation of CD11b and CD56 expression in adult acute myeloid leukemia with cytogenetic risk groups and prognosis. Annals of hematology. 2014; 93:1483-1489.

39. Coles SJ, Wang EC, Man S, Hills RK, Burnett AK, Tonks A, Darley RL. CD200 expression suppresses natural killer cell function and directly inhibits patient anti-tumor response in acute myeloid leukemia. Leukemia. 2011; 25:792-799.

40. Coles SJ, Hills RK, Wang EC, Burnett AK, Man S, Darley RL, Tonks A. Expression of CD200 on AML blasts directly suppresses memory T-cell function. Leukemia. 2012; 26:2148-2151.

41. Coles SJ, Hills RK, Wang EC, Burnett AK, Man S, Darley RL, Tonks A. Increased CD200 expression in acute myeloid leukemia is linked with an increased frequency of FoxP3+ regulatory T cells. Leukemia. 2012; 26:2146-2148.

42. Memarian A, Nourizadeh M, Masoumi F, Tabrizi M, Emami AH, Alimoghaddam K, Hadjati J, Mirahmadian M, Jeddi-Tehrani M. Upregulation of CD200 is associated with Foxp3+ regulatory $\mathrm{T}$ cell expansion and disease progression in acute myeloid leukemia. Tumour biology : the journal of the International Society for Oncodevelopmental Biology and Medicine. 2013; 34:531-542.
43. Coles SJ, Gilmour MN, Reid R, Knapper S, Burnett AK, Man S, Tonks A, Darley RL. The immunosuppressive ligands PD-L1 and CD200 are linked in AML T cell immunosuppression: identification of a new immunotherapeutic synapse. Leukemia. 2015.

44. Barclay AN, Wright GJ, Brooke G, Brown MH. CD200 and membrane protein interactions in the control of myeloid cells. Trends in immunology. 2002; 23:285-290.

45. Condamine T, Gabrilovich DI. Molecular mechanisms regulating myeloid-derived suppressor cell differentiation and function. Trends in immunology. 2011; 32:19-25.

46. Gabrilovich DI, Nagaraj S. Myeloid-derived suppressor cells as regulators of the immune system. Nat Rev Immunol. 2009; 9:162-174.

47. Moertel CL, Xia J, LaRue R, Waldron NN, Andersen BM, Prins RM, Okada H, Donson AM, Foreman NK, Hunt MA, Pennell CA, Olin MR. CD200 in CNS tumor-induced immunosuppression: the role for CD200 pathway blockade in targeted immunotherapy. J Immunother Cancer. 2014; 2:46.

48. Chen X, Eksioglu EA, Zhou J, Zhang L, Djeu J, Fortenbery N, Epling-Burnette P, Van Bijnen S, Dolstra H, Cannon J, Youn JI, Donatelli SS, Qin D, De Witte T, Tao J, Wang H, et al. Induction of myelodysplasia by myeloid-derived suppressor cells. J Clin Invest. 2013; 123:4595-4611.

49. Kretz-Rommel A, Qin F, Dakappagari N, Cofiell R, Faas SJ, Bowdish KS. Blockade of CD200 in the presence or absence of antibody effector function: implications for anti-CD200 therapy. Journal of immunology. 2008; 180:699-705.

50. Weber J. Immune checkpoint proteins: a new therapeutic paradigm for cancer - preclinical background: CTLA-4 and PD-1 blockade. Semin Oncol. 2010; 37:430-439.

51. Serafini P, Meckel K, Kelso M, Noonan K, Califano J, Koch W, Dolcetti L, Bronte V, Borrello I. Phosphodiesterase-5 inhibition augments endogenous antitumor immunity by reducing myeloid-derived suppressor cell function. J Exp Med. 2006; 203:2691-2702.

52. Noonan KA, Ghosh N, Rudraraju L, Bui M, Borrello I. Targeting immune suppression with PDE5 inhibition in end-stage multiple myeloma. Cancer Immunol Res. 2014; 2:725-731.

53. Molina AM, Lin X, Korytowsky B, Matczak E, Lechuga MJ, Wiltshire R, Motzer RJ. Sunitinib objective response in metastatic renal cell carcinoma: analysis of 1059 patients treated on clinical trials. Eur J Cancer. 2014; 50:351-358.

54. $\mathrm{Lu} \mathrm{P}, \mathrm{Yu} \mathrm{B}, \mathrm{Xu}$ J. Cucurbitacin B regulates immature myeloid cell differentiation and enhances antitumor immunity in patients with lung cancer. Cancer Biother Radiopharm. 2012; 27:495-503.

55. Vincent J, Mignot G, Chalmin F, Ladoire S, Bruchard M, Chevriaux A, Martin F, Apetoh L, Rebe C, Ghiringhelli F. 5-Fluorouracil selectively kills tumor-associated myeloidderived suppressor cells resulting in enhanced T cell-dependent antitumor immunity. Cancer research. 2010; 70:3052-3061. 